\title{
Clean and Green - The Volkswagen Emissions Scandal: Failure of Corporate Governance?
}

\section{Czysty i zielony - oszustwa emisyjne Volkswagena: klęska, czy ład korporacyjny?}

\author{
Stefan Poier
}

\author{
University of Gdansk, Institute of International Business, Chair of Marketing \\ Armii Krajowej 119/121, 81-824 Sopot, Poland \\ E-mail: s.poier.125@studms.ug.edu.pl
}

\begin{abstract}
In 2014, a scandal involving fraud and power shook the Volkswagen Group with far-reaching consequences that are yet to be fully revealed. This article examines the Volkswagen emissions scandal in terms of corporate governance failure. After a chronological review of the events that led to this extraordinarily damaging revelation, the main differences between the American and the German board system are described. Although Germany's twotier board is often considered superior to the American board system, weaknesses in the area of corporate ethics and culture that led to the crisis in the Volkswagen case are identified. The particular constellation within the Volkswagen group and its ownership structure reveals failures in management ethics that led to a certain kind of behaviour among employees that was not explicitly mandated by the management but was, nevertheless, in its interest in regard to achieving company goals.
\end{abstract}

Key words: Volkswagen, emissions scandal, corporate governance, board systems, corporate culture

\section{Streszczenie}

W 2014 r. skandal wstrząsnął Grupa Volkswagen, przynosząc daleko idące konsekwencje, z którymi firma boryka się do dzisiaj. W tym artykule przeanalizowano skandal związany z fałszowaniem danych o emisji zanieczyszczeń w Grupie Volkswagen, pod kątem niepowodzenia ładu korporacyjnego. Omówiono w porządku chronologicznym wydarzenia, które doprowadziły do ujawnienia fałszerstw i jego poważne konsekwencje, wskazując na główne różnice między funkcjonowaniem zarówno amerykańskiego, jak i niemieckiego systemu zarządzania. Chociaż niemiecka dwupoziomowa rada zarządu jest często uważana za lepszą od amerykańskiej, zidentyfikowano słabości w obszarze etyki i kultury korporacyjnej, które doprowadziły do kryzysu. Szczególny układ w grupie Volkswagena i jej struktura własności ujawnia błędy w etyce zarządzania, które doprowadziły do pewnego rodzaju zachowań wśród pracowników, które choć nie były wyraźnie nakazane przez kierownictwo, to jednak leżały w jego interesie i służyły osiąganiu celów firmy.

Słowa kluczowe: Volkswagen, skandal emisyjny, ład korporacyjny, systemy zarządzania, kultura korporacyjna

\section{Introduction}

In times of growing environmental awareness and also increasing demands on environmentally friendly products, it is becoming more and more important for companies to profile themselves as sustainable producers. Not only do consumers want environmentally friendly products out of real conviction, in addition, government regulations are becom- ing increasingly stringent to deal with growing pollution problems. The entire automotive industry in Germany achieved sales of over $€ 420$ billion in 2018. This corresponds to approximately $12.6 \%$ of the GDP (Statistisches Bundesamt, 2019). At the same time, the transport sector is also responsible for $22 \%$ of $\mathrm{CO}_{2}$ emissions and $26 \%$ of $\mathrm{NO}_{\mathrm{X}}$ emissions in Germany (Umweltbundesamt, 2019). As a result, 


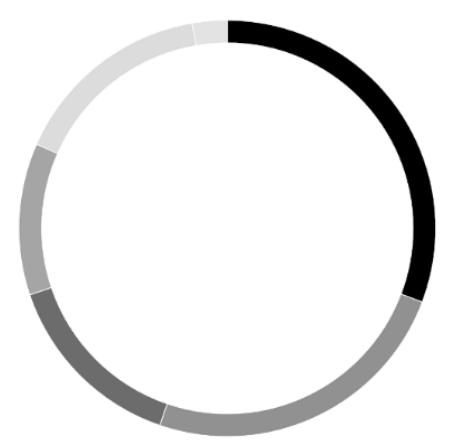

Figure 1. Volkswagen AG: Distribution of Shares

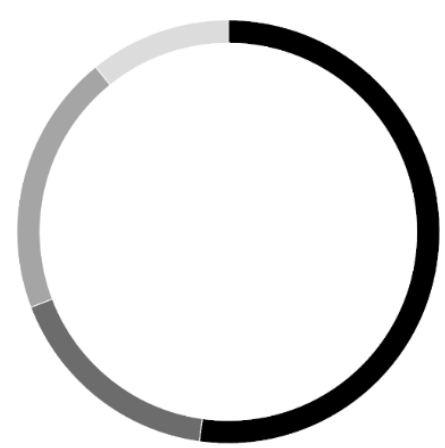

Figure 2. Distribution of Voting Shares (December 2018)

this industry offers a lucrative environment for fraudulent activities.

In 2015, the most expansive and costly scandal in the history of the company became public for Volkswagen AG - at that time one of the largest vehicle producers worldwide. Again, a car company attempted to circumvent US environmental regulations in order to gain a market advantage and increased sales through green marketing (Li et al., 2018), and again, these fraudulent activities were revealed. How could malfeasance of this magnitude go unnoticed by corporate management - if, indeed, it actually was unnoticed - for so long? How could a number of engineers install defeat devices in 11 million cars worldwide without the management's knowledge (Arbour, 2016)? And furthermore, if the management board was aware of the fraud, why didn't the supervisory board intervene? After all, with the supervisory board, the German two-tier system should have acted as a powerful controlling body vis-à-vis the Management Board.

The aim of this article is to summarise the chronology of the scandal and to critically examine the alleged advantages and limitations of the German twotier system compared to its Anglo-American counterpart.

\section{Volkswagen AG}

According to the corporation's website, the Volkswagen Group ranks among the leading automakers globally and is the largest in Europe. Volkswagen cars are available in 153 countries and
Porsche Automobil Holding SE $\mathbf{3 0 . 8}$

Foreign Institutional Investors 24.5 Qatar Holding LLC 14.6

State of Lower Saxony 11.8 Private Shareholders / Others 15.7 German Institutional Investors 2.7

Porsche Automobil Holding SE $\mathbf{5 2 . 2}$

Qatar Holding LLC 17.0

State of Lower Saxony 20.0

Private Shareholders / Others 10.8 are manufactured by more than 665,000 employees in 31 countries around the world. Currently, 12 brands belong to the Volkswagen Group: Volkswagen Pkw, Audi, SEAT, ŠKODA, Bentley, Bugatti, Lamborghini, Porsche, Ducati, Volkswagen Nutzfahrzeuge, Scania and MAN. VW's earnings after taxes amounted to 12.2 billion euros in the financial year 2018 .

Today's Volkswagen Group originated from the development of the Volkswagen or Kraft durch Freude Wagen by Ferdinand Porsche, grandfather of the late CEO, Ferdinand Piëch, who died in August 2019. After the Second World War, the factory that produced the cars was rebuilt as Wolfsburg Motor Works by the Control Commission for Germany (British Element) under the supervision of Major Ivan Hirst. Two years later, the official company name was changed to Volkswagen. Beginning in 1949 , the company was transferred to the leadership of the federal state of Lower Saxony, and the legal organisational form was changed to Volkswagen $G m b H$. In 1960, the business form was transferred to a joint-stock company and has been officially named Volkswagen $A G$ since 1985 by resolution of the annual general meeting.

In 2017, the company's pre-tax profit was 17 billion euros, and the subscribed capital of Volkswagen AG amounted to $€ 1.28$ billion. The distribution of shares is presented in Figure 1. Even more important for the balance of power within the corporation is the distribution of voting shares. In December 2018, 52.2\% were held by Porsche Automobil Holding SE, Stuttgart; $20 \%$ belonged to the federal state of Lower 
Saxony; and Qatar Holding LLC held 17.0\% (Figure 2 ). The remaining $10.8 \%$ belonged to others (Volkswagen Konzern, 2018). Porsche's subscribed capital comprises $50 \%$ ordinary shares and $50 \%$ nonvoting shares. The voting shares belong exclusively to the Piëch and Porsche families (Porsche SE, 2019). Thus, one can say that Volkswagen is mostly an Austrian family business.

In December 2007, Volkswagen launched its ambitious Strategy 2018, with its main goal being that, In 2018, the Volkswagen Group aims to be the most successful and fascinating automaker in the world (Volkswagen AG, 2010).

\section{Chronology of the Emissions Scandal}

The scandal uncovered in 2015 does not represent the first time Volkswagen was involved in fraudulent activity. In 1974, the corporation was found guilty of having manipulated the emission systems of the T2 transporter by installing defeat devices. The Environmental Protection Agency (EPA) and Volkswagen reached an agreement in the dispute. With a penalty of only $\$ 120,000$, the punishment was relatively benign (Klauder, 2015).

The legal dispute over the alleged secret betrayal by former Opel manager José Ignacio López in 1996 had been considerably more annoying. López joined Volkswagen in 1993 with seven close associates from Opel (SPIEGEL ONLINE, 1993). After the German courts failed to reach a definitive conclusion, the dispute escalated to the extent that US President Bill Clinton and German Chancellor Helmut Kohl had to intervene. Ultimately, Volkswagen was required to pay a 100-million-dollar penalty to General Motors (GM), Opel's parent company, and obliged to buy components from GM for \$1 billion. In 1996, López was pushed by Piëch to resign. The criminal case against López was suspended for a payment of 400,000 DM.

Finally, the EPA was able to prove to seven manufacturers that the manipulation with defeat devices had occurred. Without a lawsuit, Renault Trucks, Volvo Trucks, Caterpillar, Cummins Engines, Detroit Diesel, Mack Trucks, and Navistar reached an agreement with the EPA on a one-billion-dollar fine (Doll et al., 2015). At that time, at least, every company should have clearly understood the risks involved in deceiving American authorities.

Although VW stopped selling diesel vehicles in the US in 2005 because the company realised that the impending emission limits would not be met, the corporation initiated a re-entry to the American market two years later. To reach this goal, VW developed its Passat model, which was not only less expensive but also larger and better equipped than the European pendant. To attract US consumers, VW had to produce larger cars, but for US laws, especially California's environmental regulations, emissions had to be reduced - a difficult challenge to overcome (Appel, 2019). At that time, Toyota was the leading automaker worldwide, and Ferdinand Piëch was Chairman of the Supervisory Board of Volkswagen AG. He was a strong advocate of the diesel engine, and VW specialised in this technology. Diesel engines promised significantly moreeconomical fuel consumption and, thus, lower carbon dioxide $\left(\mathrm{CO}_{2}\right)$ emissions than petrol engines with the same power but, unfortunately, higher nitrogen oxide $\left(\mathrm{NO}_{\mathrm{X}}\right)$ generation. Thus, it should have been clear to upper-level and top management that only two of the three potential advantages, i.e. power, low emissions, or fuel efficiency, would be possible.

Volkswagen returned to the American market and, indeed, seemed to have convinced US consumers of the advantages of diesel cars. In 2008, the VW Jetta TDI was introduced to the US market, and in 2009, the Green Car Journal awarded it the title of Green Car of the Year, confident that it represented clean diesel.

In 2014, researchers from the International Council on Clean Transportation (ICCT), a non-profit organisation, wanted to investigate why some European car models met the strict American $\mathrm{NO}_{\mathrm{X}}$ emission limitations while, in Europe, the same cars had higher emissions. In cooperation with the University of West Virginia, the ICCT road-tested several models and found that they exceeded the limits by up to 35 times (Arbour, 2016; Siano et al., 2017). This process is complicated and expensive; therefore, cars are usually tested under laboratory conditions. Since laboratories for testing trucks are large, scarce, and even more expensive, these vehicles are usually tested on roads. Thus, in these tests conducted jointly by the ICCT and the university, some diesel trucks were found to emit less $\mathrm{NO}_{\mathrm{X}}$ than diesel cars. On May 15, 2014, the ICCT published its results.

In accordance with the Clean Air Act, the ICCT informed the Environmental Protection Agency (EPA) in Washington and the California Air Resources Board (CARB) in Los Angeles of its findings in spring 2014. The CARB conducted tests under laboratory conditions and, in contrast to the on-road tests, found no deviations from the standards (Blackwelder et al., 2018; Geoghegan, 2015). However, in the summer of 2014, the CARB managed to outsmart the defeat device under controlled conditions and, indeed, the emissions now exceeded the limits in the laboratory.

In December 2014, US authorities reached an agreement with VW that resulted in the automaker recalling about 500,000 vehicles to fix the emission problem by installing a software update. However, on-road testing conducted by the CARB revealed no improvement compared to the results before the recall. Instead of solving the problem, VW had updated the defeat devices and continued to lie to both authorities and customers. 


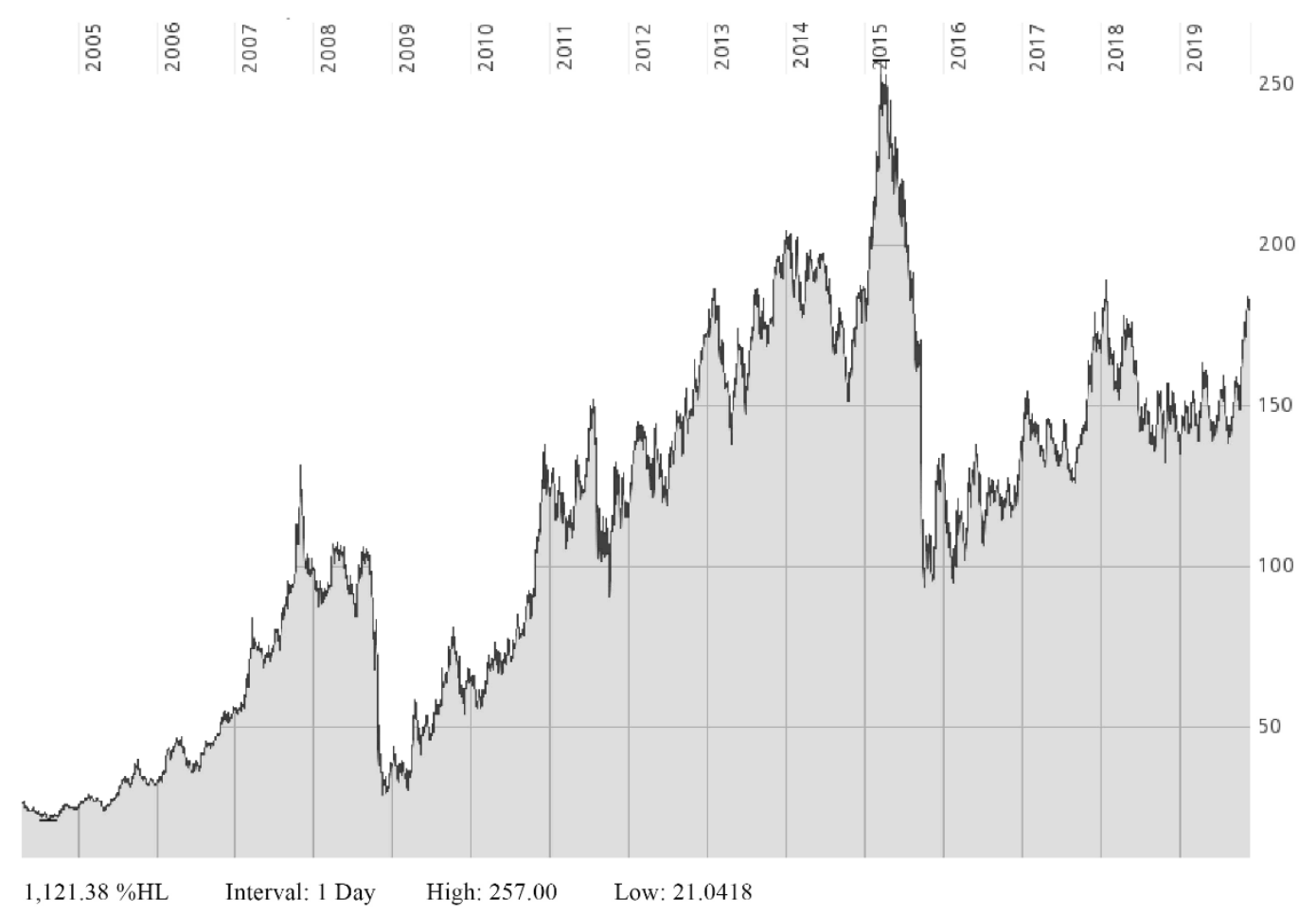

Figure 3. Performance of Volkswagen's Market Share, 2005-2019, source: www.comdirect.de

On September 23, 2015, the former CEO of Volkswagen AG, Martin Winterkorn, had to resign after engineers admitted to having implemented the defeat devices. These were originally software codes that could detect whether the car was running under real-world or laboratory conditions, and in the latter case, the $\mathrm{NO}_{\mathrm{X}}$ reduction system was activated. Thus, the cars were, indeed, equipped with the ability to reduce $\mathrm{NO}_{\mathrm{X}}-$ but it was usually deactivated. The company's stock market value fell by almost twothirds (Figure 3).

On October 8, 2015, Volkswagen's US manager Michael Horn was called to testify before a commission of inquiry and admitted that just a couple of software engineers had invented the defeat devices, without the knowledge of the management board. But after US authorities had steadily increased pressure on Winterkorn, an indictment followed against the former top manager on May 3, 2015. US Attorney General Jeff Sessions stated, If you try to deceive the United States, then you will pay a heavy price (U.S. Department of Justice, 2018).

Volkswagen had to set aside 6.5 billion euros to prepare the cars to comply with emission criteria, and while this amount is huge, it was only about half of the automaker's annual profit at the time (17.1 billion euros in 2018, 17 billion in 2017). To estimate the global scale of the scandal, one has to realise that the US market accounted for only $6 \%$ of sales, while the European and Russian markets accounted for 40\% (Ewing, 2015). Thus, if European government regulations had been as strict as those of the US, this would have been far more expensive for Volkswagen. In fact, while Volkswagen was sen- tenced to pay 25 billion dollars in fines, penalties and restitution in the US, the corporation paid not a single euro in European government penalties (Parloff, 2018).

\section{Unitary vs. Two-tier Board System}

A unitary or one-tier board system is mainly used in the United States and England and in jurisdiction under the influence of these systems, for example Canada, Australia, New Zealand and South Africa (Du Plessis et al., 2017). In contrast, the two-tier or dual board system is common in continental European states.

\section{The US unitary or one-tier board system: Board of Directors}

Corporations in the US have one-tier boards, also called a board of directors. This body combines the functions of the management board and supervisory board of a German stock corporation, namely leadership and control. Thus, it is expected to be not only more independent but also less controllable than a German company's top management. As, traditionally, the main purpose of US corporations is to maximise shareholder wealth, there is no need for an authority that represents the interests of employees or other stakeholders (Glaub, 2009). The board is represented by its chief executive officer (CEO), and most listed companies have boards comprising 8 to 12 members. Historically, the board represents a selected group of shareholders as, in the US, investors traditionally are heavily leveraged. Thus, the board 
stands for the separation of ownership and control (Berle \& Means, 1932).

Due to its compact structure and combination of managerial and supervisory tasks, the single-tier board is thought to be faster in regard to decisionmaking and the flow of information (Jungmann, 2006). Obviously, this is also the main reason for its major disadvantage: The unitary board monitors its own decisions.

\section{The German dual or two-tier board system}

German companies are subject to a whole series of governance codes: the German Stock Corporation Act (Aktiengesetz), the German Codetermination Act (Mitbestimmungsgesetz), the German Corporate Governance Code (Deutscher Corporate Governance Kodex), and the German Act on Employee Involvement in a European Company (Sharpe, 2017). As a consequence of the German Stock Corporation, all limited companies are required to have a management board (Vorstand) and a supervisory board (Aufsichtsrat), which is called a two-tier structure. Instead of focusing only on shareholder value, the two-tier board system also takes into account the interests of the stakeholders, namely codetermination and managerialism (Calkoen, 2015). In theory, the dual board structure is superior to the unitary system because of checks and balances, but in the real world, as well as in the German model, there is the possibility of egoistic decision-making in favour of shareholders' or one's own wealth maximisation (Sharpe, 2017).

\section{The Management Board}

The members of the management board, called executive officers, make strategic decisions regarding the operations of the business. They represent the corporation and are appointed and dismissed by the supervisory board. Corporations with more than three million euros in share capital must have at least two management board members; corporations with more than 2,000 employees must have a labour director, according to the Codetermination Act. Volkswagen's management board consists of eight members (Volkswagen Group, 2018).

\section{The Supervisory Board}

The supervisory board can comprise from 3 to 21 members, depending on corporation size and capital. Until an amendment to the law in 2015, the number had to be divisible by 3 . The members are appointed by the shareholders during the annual meeting and also by the employees, depending on codetermination and the size of the corporation. The task of the supervisory board is not only to control the management board's decisions ex post but also to be the bal- ancing force between all stakeholders in the corporation (Block \& Gerstner, 2016). According to its corporate website, the Volkswagen Supervisory Board is responsible for monitoring the Management and approving important corporate decisions. Moreover, it appoints the Members of the Board of Management. The Volkswagen Supervisory Board has 20 Members (Volkswagen Group, 2018).

\section{Implications for Corporate Governance}

The corporations involved in the infamous scandals of the 2000s - Enron, WorldCom, Tyco and Adelphia - were all American companies (Calkoen, 2015). Investigators were able to identify senior managers who acted egoistically and fraudulently (Crête, 2016). Thus, it could be suspected that the American board system, lacking checks and balances, would lead to such malfeasance. But regardless of the size of the corporation or the control instances, it's a people's business. Management decisions are dependent on individual values, relations and connections. If individual preferences conflict with the common good or the interests of the company, then there is no guarantee that its decision makers will not act based on self-interest (McKay et al., 2015). A study by Forbes magazine in 2011 revealed that only $30-80 \%$ of top management believed that a corporation should not only act in favour of shareholder value but should also benefit society (The Economist, 2011). Problematic against this background is the substantial exchange of personnel between industry and politics in the German auto industry. A prominent example is former Transport Minister Matthias Wissmann, who, immediately after leaving the German Bundestag, became president of the German Association of the Automotive Industry and had the opportunity to lobby intensively in an area for which he was able to set the course in his previous position (Müller, 2007).

To imagine the type of working environment and corporate culture that prevailed at VW, one should take note of the extraordinary and powerful position of Ferdinand Piëch. In the made-for-television documentary Die Akte VW-Geschichte eines Skandals (The VW Files - Story of a Scandal), automotive expert Ferdinand Dudenhöffer remarked that if an engineer did not meet Piëch's expectations during a test drive, he found a one-way ticket on his desk that suggested he be fired (Wimmer et al., 2016). This example demonstrates how employees may act in opposition to their own values and corporate social responsibility guidelines to fulfil the goals of an enterprise if there is enough pressure on them stemming from a company's ambitious goals and authoritarian leadership style (Crête, 2016; Weinstein, 2013).

As the head of the supervisory board, on one hand, and patriarch of the majority owner family, on the other, Ferdinand Piëch was able to establish a work- 
ing environment that would not tolerate contradiction or failure. As a consequence of the Porsche/Volkswagen takeover, more than half of the management positions of the supervisory board were filled by members of the Porsche and Piëch families. The remaining 10 employee representatives, according to the Codetermination Act, were not just workers but also held management positions. Thus, Piëch had no serious opposition among the supervisory board, and the management board was appointed by them. CEO Martin Winterkorn had worked with Piëch for more than 30 years. He described their relationship as follows: He makes the innovations, I secure them (Frankfurter Allgemeine Zeitung GmbH, 2015). In other words, no more and no less than whatever Piëch wanted would be implemented. In Volkswagen's press release of December 10, 2015, the corporation admitted: The starting point was a strategic decision to launch a large-scale promotion of diesel vehicles in the United States in 2005. Initially, it proved impossible to have the EA 189 engine meet by legal means the stricter nitrogen oxide requirements in the United States within the required timeframe and budget (Volkswagen AG, 2015). Thus, it was clear - and should have been obvious to the complete management hierarchy - that the fraud was a means to an end: It was impossible at that time to build an engine with the desired capabilities at the specified cost. In economic terms, one could say that the corporation was unwilling to internalise external costs. This is a global issue and the core problem of the climate change debate: Companies and private actors are causing external (environmental) costs in the present, and the costs for repairing the damages will be transferred to society in the future (Arbour, 2016). Even if damage-prevention rules already exist, they can be bypassed, and the costs of any fraudulent activities detected would be priced in (although, instead, the costs for avoiding or repairing damages should be priced in).

\section{Summary and Conclusion}

In the aftermath of the emissions scandal, the focus of many automobile tests was of course on the emission values of diesel vehicles. And just as self-evident, the manufacturers made every effort to meet the required values. The German Allgemeine Deutsche Automobilclub e.V. (General German Automobile Club, ADAC) could confirm that for example the BMW X2 xDrive20d Steptronic, the Peugeot 308 SW 2.0 BlueHDi 180 EAT8 and the Volvo XC60 D5 AWD Geartronic were able to significantly undercut the strict 6d-TEMP limits, both on the test bench and on the road (ADAC, 2018). Thus, one could assume that this progress is due to the uncovered fraud. But not the diligence of Californian researchers should have ensured this, but laws and regulations in the producing countries.
The aim of this article was to shed light on the Volkswagen emissions scandal against the background of corporate governance. This issue is not specific to VW alone because other automakers have also been suspected of having engaged in fraudulent activities. However, it would be short-sighted to conclude that there is a systemic failure of the two-tier board structure. It would be an impossible task to establish independent, external controls and regulatory authorities to oversee corporations. Wherever hierarchical structures are present and immense amounts of money are involved, egoistic behaviour cannot be ruled out. Instead, employee representatives should be encouraged to report criminal activities of the corporation that are detrimental to society without being legally liable to the company. Future research should investigate whether corporate values align with the values of management and employees or if they are intended only as lip service for marketing purposes.

\section{Funding}

This research received no specific grant from any funding agency in the public, commercial, or notfor-profit sectors.

\section{References}

1. Abgas-Skandal: Auch andere Autohersteller manipulierten Software - WELT, 2919 https://www.welt. de/wirtschaft/article148032066/Die-pure-Verzweiflu ng-trieb-Volkswagen-an.html (12.11.2019).

2. ADAC 2018, Nur noch geringer Stickoxid-Ausstoß bei neuesten Diesel-Modellen: ADAC untersucht drei Pkw mit der neuesten Schadstoffnorm Euro 6dTEMP. Auch bei ungünstigen Bedingungen sind die NOx-Messwerte niedrig, Press release, 23.04, https://www.presseportal.de/pm/7849/3923782.

3. Affäre Lopez in Der Spiegel, 1993, 52, https://www. spiegel.de/spiegel/print/d-9293792.html (12.11.2019).

4. ARBOUR M.-E, 2016, Volkswagen: Bugs and Outlooks in Car Industry Regulation, Governance and Liability, in: European Journal of Risk Regulation, 7(1), p. 4-10, DOI: $10.1017 / \mathrm{S} 1867299 X 00005316$.

5. BERLE A. A., MEANS G. C., 1932, The Modern Corporation and Private Property, Transaction Publishers, New York.

6. BLACKWELDER B., COLEMAN K., COLUNGASANTOYO S., HARRISON J. S., WOZNIAK D., 2018, The Volkswagen Scandal, in: The SAGE Encyclopedia of Business Ethics and Society ( $2^{\text {nd }}$ ed., Vol. 1), ed. Kolb R.W., SAGE Publications, Thousand Oaks, DOI: 10.4135/9781483381503.n1239.

7. BLOCK D., GERSTNER A.-M., 2016, One-Tier vs. Two-Tier Board Structure: A Comparison Between the United States and Germany (Comparative Corporate Governance and Financial Regulation No. 1), University of Pennsylvania Law School, https:// scholarship.law.upenn.edu/fisch_2016/1.

8. CALKOEN W. J. L., 2015, One- and Two-TierBoards, in: Global wisdom on business transactions, international law and dispute resolution: Festschrift 
für Gerhard Wegen zum 65 Geburtstag, eds. Sphalinger A., Wilske S., C.H. Beck, München, p. p. 147159.

9. CRÊTE R, 2016, The Volkswagen Scandal from the Viewpoint of Corporate Governance, in: European Journal of Risk Regulation, 7(1), p. 25-31, DOI: 10.1017/S1867299X0000533X.

10. DU PLESSIS J. J., GROßFELD B., SAENGER I., SANDROCK O., 2017, An Overview of German Business or Enterprise Law and the One-Tier and Two-Tier Board Systems Contrasted, in: German Corporate Governance in International and European Context ( ${ }^{\text {rd }}$ edition), eds. Du Plessis J.J., Großfeld B., Luttermann C, Saenger I., Sandrock O., Casper M., (Eds.), 16, Springer, Berlin, Heidelberg, p. 116, DOI: $10.1007 / 978-3-662-54198-2 \_1$.

11. Executive Bodies, https://www.volkswagenag.com/ en/group/executive-bodies.html (18.11.2019).

12. Ex-Verkehrsminister Wissmann wird Autolobbyist | LobbyControl, 2007, https://www.lobbycontrol.de/ 2007/03/ex-verkehrsminister-wissmann-wird-autolobbyist/ (17.11.2019).

13. Former CEO of Volkswagen AG Charged with Conspiracy and Wire Fraud in Diesel Emissions Scandal, 1919, https://www.justice.gov/opa/pr/former-ceo-vol kswagen-ag-charged-conspiracy-and-wire-fraud-diesel-emissions-scandal (17.11.2019).

14. GLAUB T., 2009, Lessons from Germany: Improving on the U.S. Model for Corporate Governance (No. 2), https://digitalcommons.law.byu.edu/ilmr/vol5/iss2/ $4 /$.

15. Gross Domestic Product (GDP), 2020, https://www. destatis.de/EN/Themes/Economy/National-Accounts -Domestic-Product/Tables/gdp-bubbles.html (15.01.2020).

16. How VW Paid $\$ 25$ Billion for Dieselgate - and Got Off Easy, 2018, https://fortune.com/2018/02/06/ volkswagen-vw-emissions-scandal-penalties/ (17.11.2019).

17. JUNGMANN C, 2006, The Effectiveness of Corporate Governance in One-Tier and Two-Tier Board Systems - Evidence from the UK and Germany, in: European Company and Financial Law Review, 3(4), DOI: 10.1515/ECFR.2006.019.

18. LI L., MCMURRAY A., XUE J., LIU Z., SY M., 2018, Industry-wide corporate fraud: The truth behind the Volkswagen scandal, in: Journal of Cleaner Production, 172, p. 3167-3175, DOI: 10.1016/j.jclepro.2017.11.051

19. Manipulierte Software: Volkswagen hat auf die falsche Technologie gesetzt, 2019, https://www.faz. net/aktuell/wirtschaft/auto-verkehr/deswegen-hat-vo lkswagen-manipuliert-13834599.html (12.11.2019).

20. Martin Winterkorn: Der Perfektionist, der Angst verbreitet, 2020, https://www.faz.net/aktuell/wirtschaft/ unternehmen/vw-vorstandsvorsitzender-martin-wint erkorn -im-portraet-13543928-p2.html (15.01.2020).

21. MCKAY D. R., NITSCH R., PETERS D. A, 2015, Corporate governance and business ethics, in: Plastic Surgery (Oakville, Ont.), 23(4), p. 271-272, DOI: $10.1177 / 229255031502300403$.
22. Milton Friedman goes on tour, 2019, https://www. economist.com/node/18010553/all-comments (17.11.2019)

23. Porsche SE, 2019, Share, https://www.porsche-se. com/en/investor-relations/share (11.11.2019).

24. SHARPE N. F, 2017, Volkswagen's Bad Decisions \& Harmful Emissions: How Poor Process Corrupted Codetermination in Germany's Dual Board Structure, in: Michigan Business \& Entrepreneurial Law Review, 7(1), p. 49-92, https://papers.ssrn.com/sol3/papers.cfm?abstract_id=3348663.

25. SIANO A., VOLLERO A., CONTE F., AMABILE S., 2017, 'More than words': Expanding the taxonomy of greenwashing after the Volkswagen scandal, in: Journal of Business Research, 71, p. 27-37, DOI: 10.1016/j.jbusres.2016.11.002.

26. Übersicht zur Entwicklung der energiebedingten Emissionen und Brennstoffeinsätze in Deutschland 1990-2017: unter Verwendung von Berechnungsergebnissen der Nationalen Koordinierungsstelle Emissionsberichterstattung, https://www. umweltbundesamt.de/publikationen/uebersicht-zur-entwicklung-der-energiebedingten-0 (15.01.2020).

27. Volkswagen Group, Annual Report 2009, https://www.volkswagenag.com/presence/investorrelation/publications/annual-reports/2010/volkswag en/Y_2009_e.pdf (17.11.2019).

28. Volkswagen Group, Strategy 2018, https://www. volkswagenag.com/managementreport/reportonexpecteddevelopments/strategy/strategy2018.html (17.11.2019)

29. Volkswagen making good progress with its investigation, technical solutions, and Group realignment, https://www.volkswagen-newsroom.com/en/pressreleases/volkswagen-making-good-progress-withits-investigation-technical-solutions-and-group-realignment-1681 (17.11.2019).

30. Volkswagen Konzern: AR 2017 - Shareholder structure, 2017, https://annualreport2017.volkswagenag. com/group-management-report/shares-and-bonds/ shareholder-structure.html (11.11.2019).

31. Volkswagen Says 11 Million Cars Worldwide Are Affected in Diesel Deception, 2015, https://www.nytimes.com/2015/09/23/business/international/volksw wagen-diesel-car-scandal.html (17.11.2019).

32. Vor 41 Jahren musste VW schon mal zahlen, 2019, https://www.auto-motor-und-sport.de/news/vw-abga sskandal-vor-41-jahren-musste-vw-schon-mal-zahlen/ (12.11.2019).

33. VW's Emissions Cheating Found by Curious CleanAir Group, 2015, https://www.bloomberg.com/news/ articles/2015-09-19/volkswagen-emissions-cheatingfound-by-curious-clean-air-group (17.11.2019).

34. WEINSTEIN S. (ed.), 2013, Legal risk management, governance and compliance: A guide to best practice from leading experts, Globe Law and Business, London.

35. WIMMER A., SCHEUNERT A., KERN M., 2016, 2016, Die Akte VW - Geschichte eines Skandals [Television broadcast], ZDF/ARTE, 1.06. 
